\title{
GROWTH AND ROOTING SYSTEM OF ACACIA MANGIUM OBTAINED BY TISSUE CULTURE
}

\author{
IWANSETIAWAN, M.I. UMBOHand SUPRIYANTO \\ SEAMEO BIOTROP, P.O. BOX 17, Bogor, Indonesia
}

\section{INTRODUCTION}

Since 1980/1981, the government of Indonesia through the Ministry of Forestry has started to reforest logged-over, alang-alang, unproductive areas and to convert them to Forest Industry Plantation. The target is 300000 ha per year. It means, 750 million seedlings should be provided per year (planting distance $2 \mathrm{~m} \times 2 \mathrm{~m}$ ).

The tree species to be planted in forest industry plantation should have shorter life cycle (8 - 10 years), good stem-form, good rooting system, and should be fast growing. Acacia mangium has been selected as one of the important tree species for forest industry plantation due to its growth, quality of fiber wood (pulp and paper industry) and rooting system (produce a lot of secondary root and nitrogen fixater) (Soebardjo 1986). The reforestation of logged-over Dipterocarp forests in Malaysia with A. mangium has also been considered (Appanah and Weinland 1989).

Generally, reforestation with A. mangium is done with seedlings obtained by seed germination. A. mangium produce a lot of seeds but its production is still limited by the season, while the conventional method of vegetative propagation through cuttings gave very low percentage of rooted-cuttings (1\%) (Umboh and Syamsul Yani 1989).

The micropropagation of $A$. mangium through tissue culture is a promising method. The production of $A$. mangium plantlets through that method has been done at the Forest Genetic Laboratory, Tropical Forest Biology, SEAMEO BIOTROP (Situmorang 1988, Umboh 1988, Umboh et al. 1989, 1990). These rooted-plantlets (plantlings) were first put in the green house (acclimatization) before planting in the field.

Field tests of some agricultural plants have been done but information on forest trees species is still lacking because the production of plantlings through tissue culture is still limited as there are still problems of their rooting. In fact, the progress of reproducing woody plants by tissue culture has been much slower than with herbaceous plants. The major reason for this limited success with forest trees appears to be due to lack of efforts and because it takes longer time than herbaceous plants (Durzan and Campbell 1974). Generally, rooted-cuttings or rooted-plantlets do not produce tap root, but secondary roots only. The most frequent origin of adventitious roots are the cambium, phloem and pericycle. It is less frequent for 
the cortex, pith and xylem (Haissig 1974). The time and place of initiation of induced root primordia vary greatly among species (Kramer and Kozlowski 1979). The rooting system will influence the growth pattern of the rooted-cuttings or plantlings.

The objective of this study is to observe the growth and rooting system of $A$. mangium obtained by tissue culture in the field. The information gathered will be used for sylviculture and genetic study of A. mangium plantlings.

\section{MATERIALS AND METHOD}

The plantlings of A. mangium were obtained by tissue culture method described previously by Umboh and Syamsul Yani (1990). During the acclimatization period, the plantlings were planted in mixed soil-sand medium (1:1) for one month and green house conditions. After 4 months in the green house, the plantlings were transferred to the field (Figure 1). Forty plantlings (50-60 cm high) were planted in the field at $3 \mathrm{~m} \mathrm{x} 3 \mathrm{~m}$ planting distance. To avoid strong direct sunlight, simple shading with alang-alang leaves was implemented.

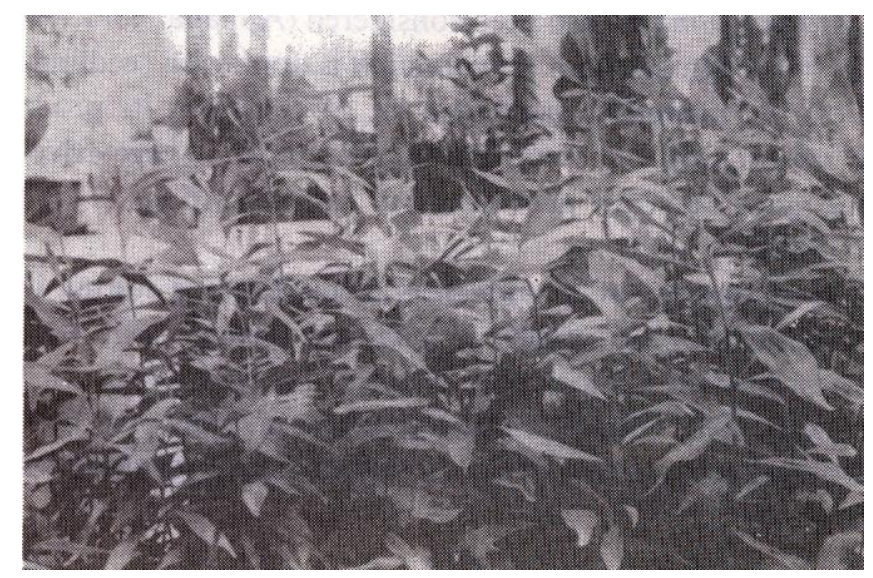

Figure 1. Four-month old A. mangium plantlings before planting in the field.

The experimental site is located at the Forest Research and Development experimental garden, Cikarawang, Darmaga, Bogor. The area was dominated by Imperata cylindrica (alang-alang), open area, $244 \mathrm{~m}$ a.s.l. and $3552 \mathrm{~mm} / \mathrm{year}$ rainfall. The soil type is red brown latosolic and is very fertile up to $1 \mathrm{~m}$ soil depth. 
The height and diameter growth rate were measured once a month. The clear-bole height was also recorded. To confirm its rooting system, two trees were dug and compared with other A. mangium trees obtained from seed germination, of the same age, at $2 \mathrm{~m} \times 2 \mathrm{~m}$ planting distance, situated 150 meters from the field test and planted by the Forest Research and Development Center, Gunung Batu, Bogor. This plantation is designated for provenance trials of A. mangium.

\section{RESULTS AND DISCUSSION}

The height and diameter growth rate of A. mangium plantlings are shown in Figures 2 and 3. During the 2.5 years of field test, some important developments were observed:

- During the first six months, the plantlings were trying to adapt to field conditions. The mean height growth was slow ( $0.5 \mathrm{~m}$ whithin 6 months) and diameter increment was very low.

- During the second six months the stems were more vigorous and some branches were formed. The mean increase in height was $1.5 \mathrm{~m}$ within 6 months. It was

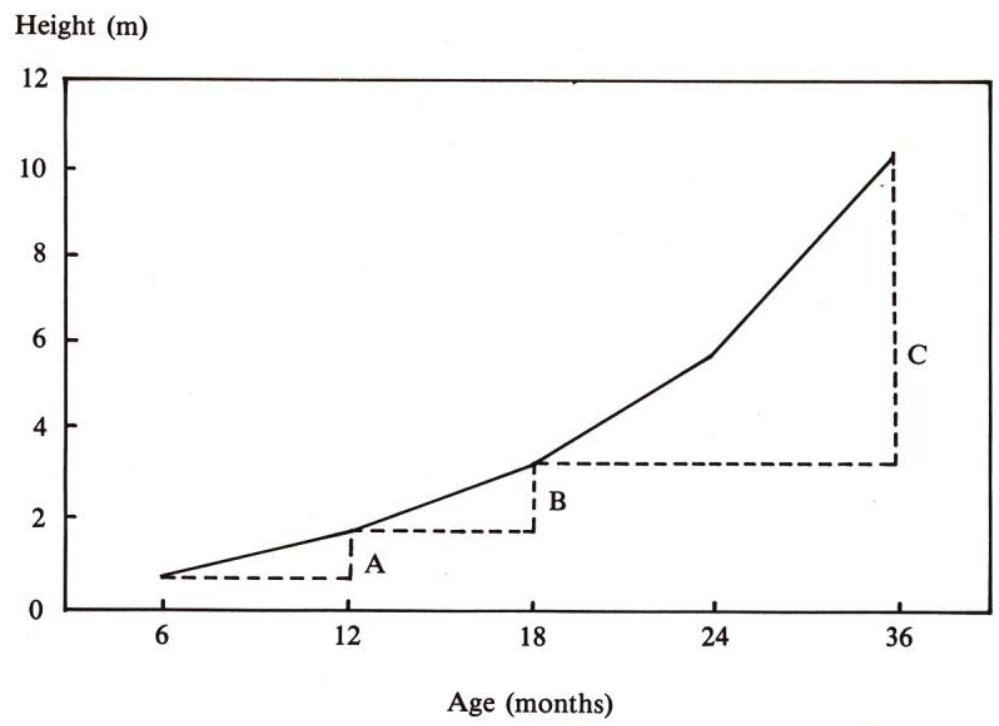

Figure 2. Height growth of A. mangium tree obtained by tissue culture.
A : Growth during adaptation period
B : Growth after adaptation period
$\mathrm{C}$ : Growth during maturation period 


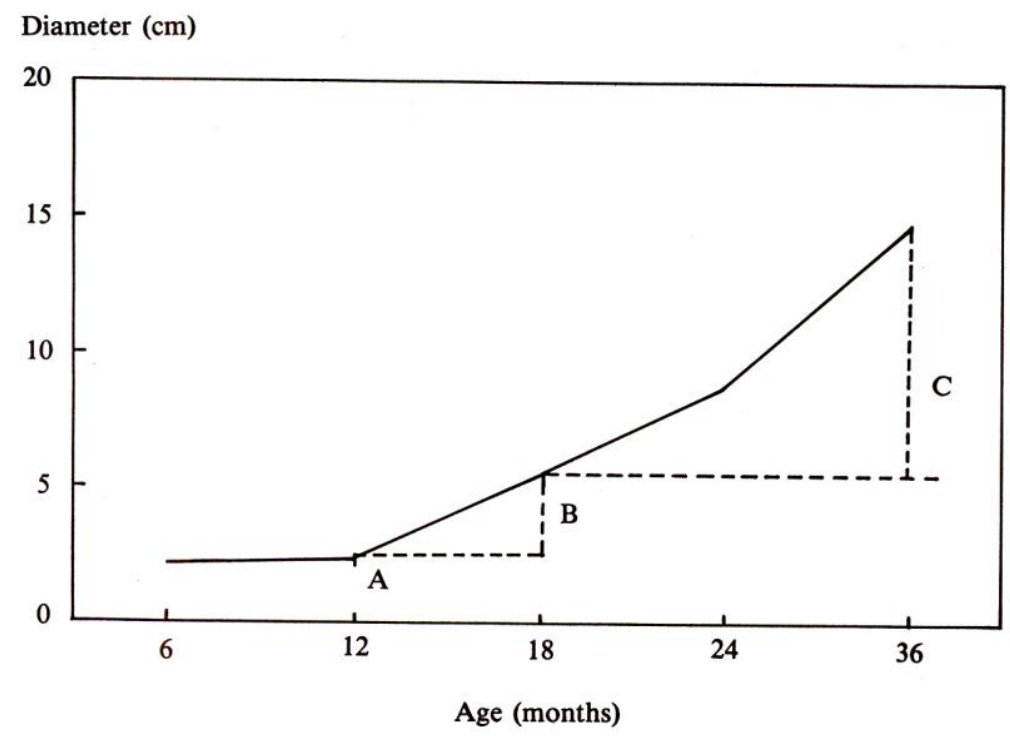

Figure 3. Diameter growth of A. mangium tree obtained by tissue culture.

faster than during the first six months and the mean diameter increment was more evident ( $2.5 \mathrm{~cm}$ within 6 month).

- After one year of planting, the mean height increased remarkably (3.5 m within 6 months) and $4.5 \mathrm{~cm}$ within 6 months for mean diameter growth rate. Many branches at the lowest level broke off naturally (natural pruning).

The natural pruning of branches can reach up to 3/4 of the tree height among seed germinated trees because the planting distance is very close (Figures $4 \mathrm{a}$ and $4 \mathrm{~b}$ ). Since the planting distance among the $A$. mangium plantlings was greater, lower natural pruning $(1 / 2$ of tree height) was observed together with more branching (Figure 5a). The mean height, diameter and height clear-bole of $A$. mangium plantlings after 2.5 years of field test were $10.3 \mathrm{~m}, 15 \mathrm{~cm}$ and $5 \mathrm{~m}$, respectively. In the Philippines, the height of 3 -year old $A$. mangium (from seed germination) reached up to $8.3 \mathrm{~m}$ and $9.3 \mathrm{~cm}$ in diameter, without mentioning its soil type. While in Bangladesh, A. mangium (from seed germination) planted in good soil condition grew up to $8 \mathrm{~m}$ in height and $15 \mathrm{~cm}$ in diameter (Soebardjo 1986). The height and diameter growth of A. mangium obtained by tissue culture were better than those obtained from seed germination. This might be caused by its rooting system and soil fertility. A tree has a good rooting system if the secondary roots develop well and has some vertical roots.

The volume of soil occupied by the roots is an important factor in determining the amount of minerals and water available to trees. Roots of forest trees tend to 
Growth and rooting system of Acacia mangium-I. Setiawan, M.I. Umboh \& Supriyanto

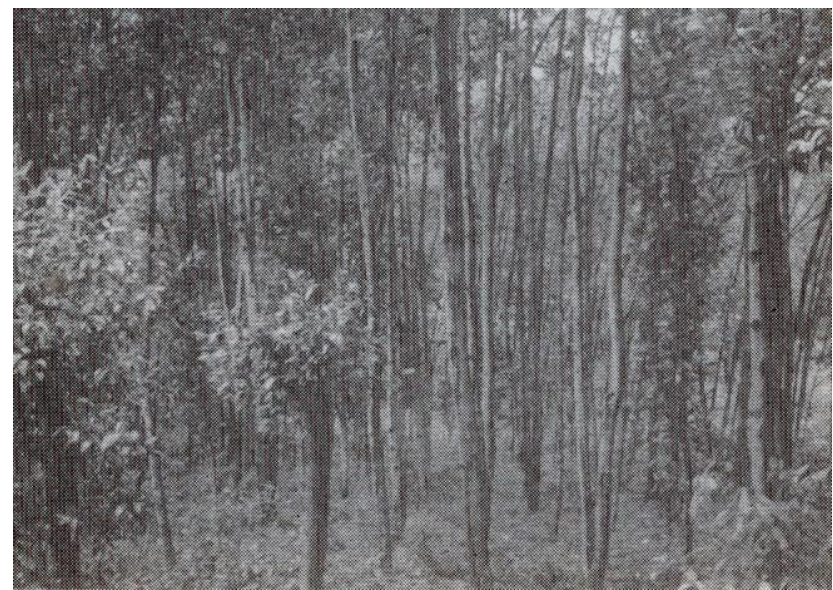

Figure 4a. Plantation of A. mangium, 2.5 years old, 2 × 2 m planting distance, obtained from seed germination. Provenance trial at the Research Institute of Forestry Cikarawang, Bogor.

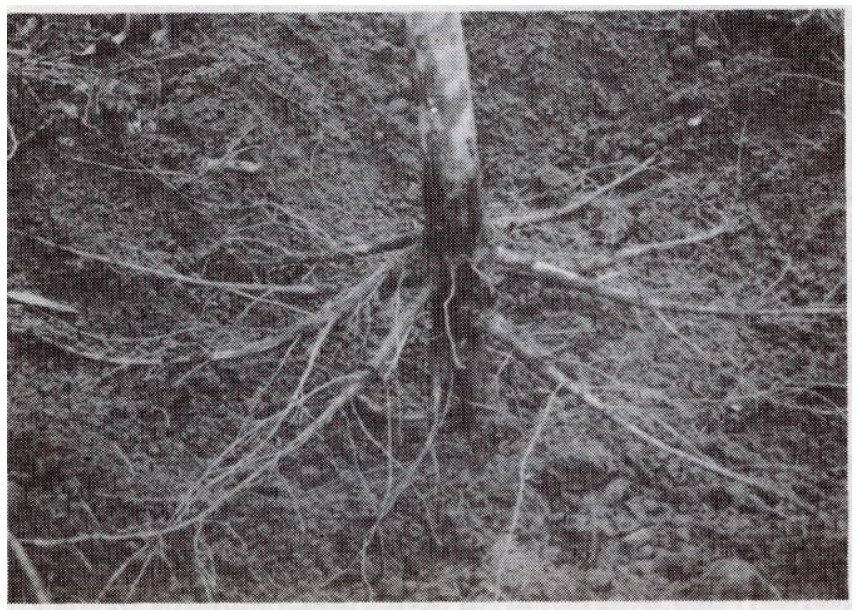

Figure $4 \mathrm{~b}$. The rooting system of A. mangium obtained from seed germination, 2.5 years old, planting distance $2 \times 2 \mathrm{~m}$. 


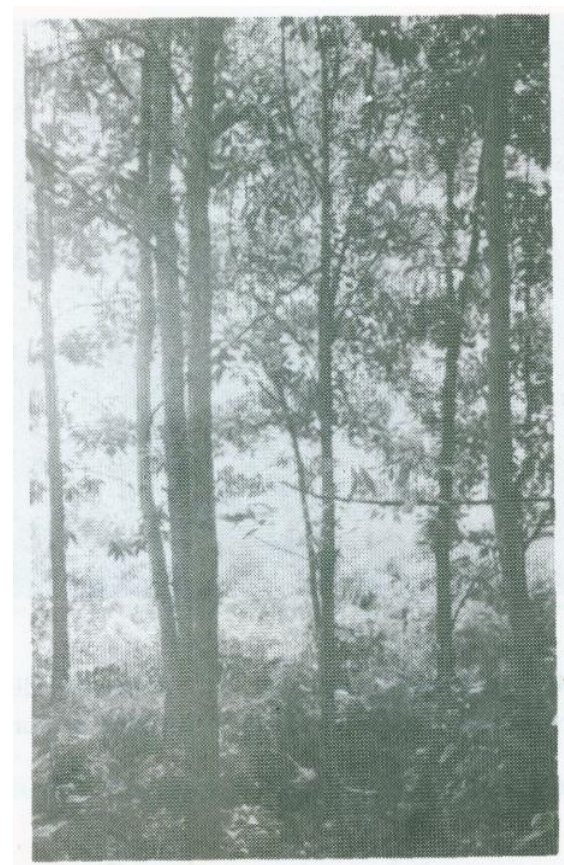

Figure 5a. The plantation of A. mangium produced by tissue culture, 2.5 years old, $3 \times 3 \mathrm{~m}$ planting distance.

form a dense mat on the surface of soil intercepting minerals released by decaying litter (Russel 1973). Based on the observations of the root formation and development, $A$. mangium trees obtained by tissue culture produce a lot of lateral roots (secondary roots) but no tap root. Three to four adventitious roots initiated in vitro developed as main roots and some vertical roots were also formed (Figure 5b). The number of secondary roots (bigger than $0.5 \mathrm{~cm}$ diameter) was 20-30. In the nursery, the formation of secondary roots can be stimulated by cutting the tap root (Abod 1984). A. mangium trees obtained from seed germination formed tap roots and less lateral roots. Since the tap root is still being formed, the formation of lateral roots was inhibited. Consequently, the mineral absorbtion in this system is less efficient than in trees obtained by tissue culture.

Sylviculturally, this field test gives better understanding of the growth pattern, rooting system and ecological adaptation of $A$. mangium produced by tissue culture. Since its growth (height and diameter) and rooting system are very good, seedlings production through tissue culture should be used in reforestation programme specially for Forest Industry Plantation. 


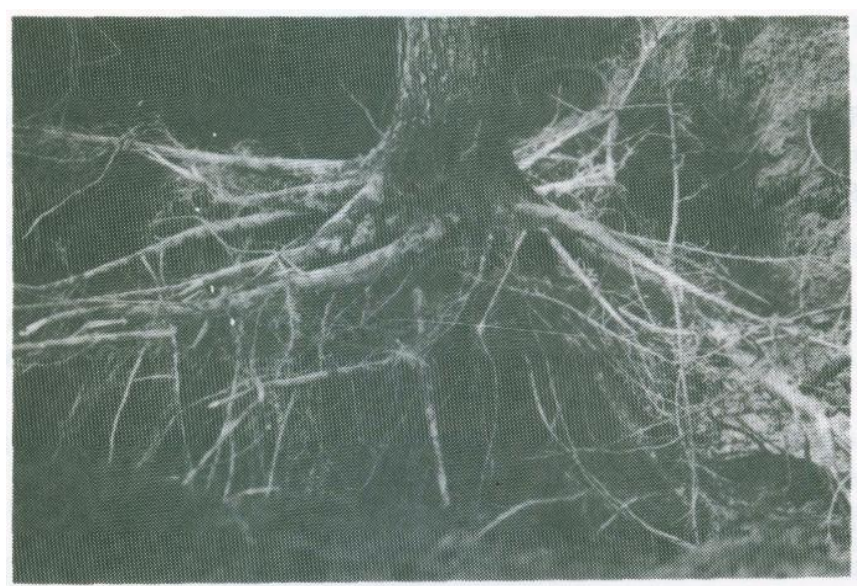

Figure $5 \mathrm{~b}$. The rooting system of A. mangium obtained by tissue culture, 2.5 years old, planting distance $3 \times 3 \mathrm{~m}$.

These results should be supplemented either by cytological or electrophoretic studies before proceeding to the clone trees in bigger quantity because most seedlings obtained by tissue culture (plantlings), specially callus culture, produce high genetic variability (D'Amato 1975; Berljak 1984).

From the wood technology point of view, the wood qualities of A. mangium that need to be examined include hardness and the fiber length. Since tissue culture of forest trees is relatively new, there is little information on wood quality of trees produced by tissue culture. The main constraint is the fact that forest trees take longer time to grow than agricultural plants (fruit trees). Fortunately, the life cycle of A. mangium is very short compared to other forest trees $(6-8$ years for Albizia falcataria, 35 year for dipterocarps, 6-100 years for Tectona grandis). Since A. mangium is used also for pulp and paper industry, the examination of fiber quality is also needed, i.e. possible improvement of fiber length.

\section{CONCLUSIONS}

1. Regarding the height and diameter growth after 2.5 year of field test, A. mangium trees produced by tissue culture grow better than those obtained by seed germination.

2 . The rooting system of $A$. mangium produced by tissue culture is very compact, massive, and with a lot of secondary roots. Although there is no tap root, 3-4 adventitious roots developed vertically and assumed the same function as tap root. 


\section{REFERENCES}

ABOD, S.A. 1983. The Effect of Restricted Watering, Root Pruning and Their Combination on Root Regenerating Potential and the Growth of Pinus merkusii seedlings. Research Report, SEAMEO BIOTROP, Bogor, Indonesia.

BERLJAK, J.C. 1984. Micropropagation of Black Pine (Pinus nigra Arn). Abst. Msc. Thesis, Univ. Zagreb. DJAmato, F. 1975. The Problem of Genetic Stability in Plant Tissue and Cell Cultures In: Crop Genetic Resources for Today and Tomorrow (Eds. Frankel, O.H. and J.G. Hawkes). Cambridge Univ.

DURZAN, D.J. and R.A. CAMPBELL. 1974. Prospects for the mass production of improved stock of forest trees by cell and tissue culture. Ca. J. For. Sci. 4: 151-174.

HAISSIO, B.E. 1974. Origins of Adventition Roots. N.Z. J. For. Sci. 4: 229-310.

KRAMER, P.J. and T.T. KOZLOWSKI. 1979. Physiology of Woody Plants. Academic Press Inc., New York, San Francisco, London.

RUSSEL, E.W. 1973. Soil Conditions and Plant Growth. 10th Ed. Longmans, Green, New York. SOEBARDJO. 1986. Penanaman Eucalyptus sp. dan Acacia mangium di Areal HPH PT. Arara Abadi Kumpulan Makalah Seminar dan Reuni IV Fakultas Kehutanan, Universitas Gadjah Mada, Yogyakarta 11-12 September 1986.

UMBOH, M.I.J. 1988. Production of Acacia mangium Willd. Plantlets by in vitro Vegetative Propagation. In: The Application of Tissue Culture Techniques in Economically Important Tropical Trees. BIOTROP Special Publication No. 35. SEAMEO BIOTROP, Bogor: 87-96.

UMBOH, M.I.J. and SYAMSULA. YANI. 1989. Micropropagation of some selected Acacia mangium trees from Subanjeriji Forest Plantation. In: Seminar on Forest Tree Tissue Culture, Organized by Winrock Int. and Plantek Int. Ltd., 17-18 August 1989, Singapore.

UMBOH, M.I.J., IWANSETIAWAN, HANIF KAMIL, SYAMSULA. YANI and J. SITUMORANO. 1989. L'application de techniques de culture in vitro a la multiplication d'especes forestieres tropicales en Indonesie. Bull. Soc. Bot. Francais, 136, Actuall Bot. (3/4): 179-184.

UMBOH,M.IJ., SYAMSULA. YANIand J. SITUMORANG. 1990. Pengadaan bahan tanam Acacia mangium dan Eucalyptus urophylla dari beberapa pohon pilihan di hutan tanaman Subanjeriji. In: Seminar on Biotechnology for Forestry, held by PAU, University of Gadjah Mada, 12-13 February 1990, Wanagama, Yogyakarta. 